University of Chicago Law School

Chicago Unbound

Journal Articles

Faculty Scholarship

1968

\title{
Uninhibited, Robust, and Wide-Open: A Note on Free Speech and the Warren Court
}

Harry Kalven Jr.

Follow this and additional works at: https://chicagounbound.uchicago.edu/journal_articles

Part of the Law Commons

\section{Recommended Citation}

Harry Kalven, Jr., "Uninhibited, Robust, and Wide-Open: A Note on Free Speech and the Warren Court," 67 Michigan Law Review 289 (1968).

This Article is brought to you for free and open access by the Faculty Scholarship at Chicago Unbound. It has been accepted for inclusion in Journal Articles by an authorized administrator of Chicago Unbound. For more information, please contact unbound@law.uchicago.edu. 


\title{
"UNINHIBITED, ROBUST, AND WIDE-OPEN"- \\ A NOTE ON FREE SPEECH AND THE WARREN COURT
}

\author{
Harry Kalven, Jr.*
}

$\mathrm{T}$

HERE are several ways to give at the outset, in quick summary, an over-all impression of the Warren Court in the area of the first amendment. The quotation in the title can for many reasons be taken as its trademark. The quotation comes, of course, from a statement about public debate made in the Court's preeminent decision, New York Times $v$. Sullivan, ${ }^{1}$ and it carries echoes of Alexander Meiklejohn.' TWe have, according to Justice Brennan, "a profound national commitment to the principle that debate on public issues should be uninhibited, robust, and wide-open . . .."3 What catches the eye is the daring, unconventional selection of adjectives. These words capture the special quality of the Court's stance toward first amendment issues. They express the gusto and enthusiasm with which the Court has tackled such issues. They indicate an awareness that heresy is robust; that counterstatement on public issues, if it is to be vital and perform its function, may not always be polite. And, most significantly, they express a desire to make a fresh statement about the principles of free speech rather than simply repeat the classic phrases of Holmes in $A_{b r a m s}^{4}$ and Brandeis in Whitney. 5 The Court is interested enough to be minting contemporary epigrams-to be making it its own.

For a further impression of the Court's work in the first amendment field, we might turn to the 1959 case involving Lady Chatterly's Lover in movie form, Kingsley Pictures Corp. v. Regents. ${ }^{6}$ Chiefly because of an inability to agree on precisely how the court below had disposed of the case, the Supreme Court, although unanimous in reversing, found it necessary to produce six separate opinions. ${ }^{7}$ Of particular interest for the moment is Justice Stewart's opinion: he

\footnotetext{
- Professor of Law, Lniversity of Chicago. A.B. 1935, J.D. 1938, University of Chicago. - Ed.

1. 376 U.S. 254 (1964).

2. Meiklejohn, Free Speech in Relation to Self-Government, republished in A. Meiklejohn, Political Frfedox (1960); cf. Kalven, The New Yotk Times Case: A Note on the Central Meaning of the First Amendment, 1964 Sup. CT. REv. 191, 221; Brennan, The Supreme Court and the Meiklejohn Interpretation of the First Amendment, 79 HARv. L. REv. 1 (1965).

3. 376 U.S. 254, 270 (1964).

4. Abrams v. United States, 250 C.S. 616 (1919).

5. Whitney v. California. $27 \pm$ C.S. 357 (1927).

6. 360 U.S. 684 (1959). 28-34.

7. See Kalven, The Metaphysics of the Law of Obscetrity, 1960 Sup. Cr. Rev. 1,
} 
read the court below as banning the movie because it had dealt too sympathetically with adultery. In meeting this objection he was moved to restate the basic principle with notable freshness:

It is contended that the State's action was justified because the motion picture attractively portrays a relationship which is contrary to the moral standards, the religious precepts, and the legal code of its citizenry. This argument misconceives what it is that the Constitution protects. Its guarantee is not confined to the expression of ideas that are conventional or shared by a majority. It protects advocacy of the opinion that adultery may sometimes be proper no less than advocacy of socialism or the single tax. And in the realm of ideas it protects expression which is eloquent no less than that which is unconvincing. ${ }^{8}$

Again what strikes the special note is not just the firm grasp of the basic principle but the gallantry, if you will, of its restatement. It is easier to champion freedom for the thought we hate than for the thought that embarrasses.

Yet another way of reducing to quick summary the special quality of this Court with regard to first amendment issues is to compare the opinions in Curtis Publishing Company v. Butts, ${ }^{\circ}$ decided in 1967, with the opinion in Debs $v$. United States. ${ }^{10}$ The Debs case was decided March 10, 1919, exactly one week after Schenck ${ }^{11}$ had launched the clear-and-present-danger formula. In an opinion by Justice Holmes, the Court affirmed Debs' conviction (carrying a tenyear prison sentence) for attempting to incite insubordination, disloyalty, mutiny, and refusal of duty in the armed forces and for attempting to obstruct the recruiting and enlistment service of the United States in violation of the Espionage Act of 1917. The overt conduct of Debs consisted solely in making a public speech to a general adult audience in Canton, Ohio. At the time he was a major national polifical figure, and in 1920 he was to run as the Socialist candidate for President from prison and receive over 900,000 votes. ${ }^{12}$

The speech itseif, which is summarized in Justice Holmes' opinion, involved a criticism of war in general and World War I in particular from a Socialist point of view. It asserted, for example, that "the master class has always declared the war and the subject class has always fought the battles . . ." ${ }^{13}$ It expressed sympathy for several others already convicted for their opposition to the war, say-

8. 360 U.S. at $688-89$.

9. 388 U.S. 130 (1967).

10. 249 U.S. 211 (1919).

I1. Schenck v. United States, 249 U.S. 47 (1919).

12. There is a discussion of the case and its background in Z. CHAFEE, FreE SpEECH iN THE UNITED StATES 84-86 (1941).

13. 249 U.S. 211,213 (1919). 
ing that "if they were guilty so was he."14 It appears that most of the speech was devoted to Socialist themes apart from the war, and it concluded with the exhortation: "Don't worry about the charge of treason to your masters; but be concerned about the treason that involves yourselves." 15 During the trial Debs addressed the jury himself and stated: "I have been accused of obstructing the war. I admit it. Gentlemen, I abhor war. I would oppose the war if I stood alone."16

The Court disposed of the case in a perfunctory two-page opinion, treating as the chief question whether a jury could find that "one purpose of the speech, whether incidental or not does not matter, was to oppose not only war in general but this war, and that the opposition was so expressed that its natural and intended effect would be to obstruct recruiting." 17 The first amendment defense exacted only the following sentence from Justice Holmes: "The chief defenses upon which the defendant seemed willing to rely were the denial that we have dealt with and that based upon the First Amendment to the Constitution, disposed of in Schenck $v$. United States ...."18 The decision was unanimous and without any comment from Justice Brandeis. ${ }^{10}$

Let us now jump a half century to Butts. At issue there was a judgment under state law in a libel action brought by a noted football coach against a national magazine for an article which in effect accused him of "fixing" a college football game by giving his team's secrets in advance of the game to the opposing coach. The case produced an elaborate outpouring of opinions and an intricate pattern of votes in the five-to-four decision affirming the judgment. All Justices agreed that since Butts was a public figure, the reporting of his activities was in.the public domain and therefore the state libel law was subject to the discipline of the first amendment. The Justices divided over what level of privilege the defendant publisher must be given to satisfy the constitutional concern with freedom of

\footnotetext{
14. 249 U.S. at 214.

15. 249 U.S. at 214.

16. 249 U.S. at 214 .

17. 249 U.S. at 215.

18. 249 U.S. at 215. Holmes' reaction makes it evident that the clear-and-presentdanger dictum did not in his mind become a constitutional test until sometime after Schenck. Professor Chafee has suggested Holmes was waiting for Abrams: "Looking backward, however, we see that Justice Holmes was biding his time until the Court should have before it a conviction so clearly wrong as to let him speak out his deepest thoughts about the First Amendment." Z. ChafeE, FREe SPEECH in the UNITED States 86 (1941). It would be a worthwhile task to explore what it meant about Justice Holmes that he could see Abroms but not Debs as the "clearly wrong" case.

19. It did, however, evoke an eloquent shocked dissent from Professor Ernst Freund of The University of Chicago Law School. See Freund, The Debs Case and Freedom of Speech, NEw REPUBLIC, May 3, 1919, at 13.
} 
speech. Three separate positions were expressed: Justices Black and Douglas would have granted an absolute or unqualified privilege not defeasible by any showing of malice. At the other extreme, Justice Harlan, joined by Justices Clark, Fortas, and Stewart, held the privilege defeated by a showing of "highly unreasonable conduct constituting an extreme departure from the standards of investigation and reporting ordinarily adhered to by responsible journalists." The middle ground was occupied by Justices Brennan, White, and the Chief Justice, who would have adhered to the standards set forth in New York Times and thus would have held the privilege defeasible by actual malice-defined as "knowing falsehood or reckless disregard for truth." Out of this unpromising and apparently trivial factual context came deeply felt essays on freedom of speech by Justices Harlan, Black, and the Chief Justice. ${ }^{20}$ In wondering about all this on another sccasion, I observed:

This is perhaps the fitting moment to pause to marvel at the pattern of the Court's argument on this issue. The Court was divided 5 to 4 on whether the constitutional standard for the conditional privilege of those who libel public figures is that it be defeasible only upon a showing of reckless disregard for truth or merely on a showing of an extreme departure from professional newspaper standards! Further it was understood that the chief significance of the standard relates simply to how jury instructions will be worded. Yet this nuance triggered a major debate in the court on the theory of free speech. ${ }^{21}$

And in speculating on why these issues held such extraordinary power to move the Supreme Court-after noting that in the sequence of cases following New York Times the Court had located a novel and difficult issue involving "public speech interlaced with comments on individuals"-I could only add: "Second, it shows once again-and it is a splendid thing-that all members of this Court care deeply about free speech values and their proper handling by law. Only a concerned Court would have worked so hard on such a problem."22

The difference between Debs and Butts is a measure of how much the Court's approach to free speech has changed over the years since World War I. And it is a difference, it will be noted, in result, in theory, in style, and, above all, in concern. ${ }^{23}$

20. The details on the judicial patterns are analyzed in Kalven, The Reasonable Man and the First Amendment: Hill, Butts and Walker, 1967 Sur. Cr. REv. 267.

21. Id. at 307 .

22. Id. at 308 .

23. Of course, by no means is all of this difference to be attributed to the Warten Court, but see text part II infra. Two other recent decisions clamor for comparison with the Debs case: Bond v. Floyd, 385 U.S. 116 (1966), where the Court enjoined the 
But even as one acknowledges the deep concern of this Court for the first amendment, there is need to pause at the outset for a perplexity and an irony. The perplexity is one that must have troubled all the contributors to this Symposium: What exactly is one referring to when he speaks of the Warren Court?24 Are we simply using the Chief Justiceship as a device to mark off a span of years? Would it have been any more arbitrary to talk of the work of the Court from, say, 1958 to 1964? If we find some distinctive traits in that work, as both friends and critics of the Court are so readily prone to do in the first amendment area, to whom are we ascribing them? To some durable team of Justices? To the special influence of the Chief? The Court's roster during the Warren years has included some seventeen Justices, and the "Warren Court" has for varying periods of time numbered among its members Justices Minton, Burton, Glark, Whittaker, Reed, Jackson, Goldberg, and Frankfurter. ${ }^{25}$ Perhaps we should adapt the old Greek conundrum and ask if we can comment on the same Court twice.

I would hesitate to adopt the alternative and say that what unifies the topic is the distinctive influence of the Chief Justice on the Court's response to the first amendment. This would require not only that we find a distinctive pattern of decisions, but that we connect it up somehow to the chairmanship of the Chief-which seems to me to attribute excessive power to that office.

But perhaps I am being too solemn about it all. There has indeed been a kind of first amendment team: Black and Douglas have been on the Court during the entire tenure of the Chief Justice. Brennan and Harlan were appointed in 1956, and Stewart in 1958. And it is the analysis and response of these six Justices to the first amendment that $I$ have chiefly in mind in considering the Warren

Georgia legislature from refusing to seat Julian Bond for making a speech expressing "sympathy and support for the men in this country who are unwilling to respond to a military draft"; and United States v. O'Brien, 391 U.S. 367 (1968) where the Court upheld against a first amendment challenge the federal statute making it a felony knowingly to destroy or mutilate a draft card. In some respects the $O^{\prime} B$ rien case is reminiscent of the Court's response in Debs and perhaps indicates that no Supreme Court has yet acted with much independence about speech during wartime. In any event, one careful commentator has found the treatment of the first amendment issues in the O'Brien case "astonishingly cavalier." Alfange, Free Speech and Symbolic Conduct: The Draft Card Burning Case, 1968 SuP. CT. REv. 1.

24. It should be acknowledged that Professor Cox in his lively and lucid review of the Court's work was able to proceed effectively without any prefatory worries over the unity of the topic. A. Cox, ThE WARREN COURT (1968). The book begins: "The appointment of Earl Warren as Chief Justice of the United States in 1953 marked the opening of a new period in our constitutional development."

25. See the convenient chart of the Justices in W. LockrfarT, Y. RAMrsar, \& J. Choper, Constitutional Rights and LIberties, app. A (2d ed. 1967). 
Court's reaction to free speech issues. ${ }^{26}$ At least we match here the rough unity of topic provided, say, by talk of the greatness of the New York Yankees in the middle 1920's. ${ }^{27}$

The irony, of course, is that it is still the Warren Court-at least temporarily. Due to the vagaries of everyone's politics, the October term has opened with Earl Warren back in his customary center seat. The wretched controversy over the Fortas appointment was interpreted widely as an attack more on the Court as a whole than on Justice Fortas. The Senate was presumably providing its own commentary on the work of the Warren Court. And for our immediate purposes, it is striking how much of the Senate's concern was with the work of the Court in the first amendment area. There is a temptation to brood over the gap which appears to have been created between the first amendment values the Court has championea and those the public, or a considerable segment of the public, will tolerate. Is there, then, a political limit on the meaning of the first amendment? Two offsetting considerations should, in any event, be noted. The Senate's free-speech grievances related almost exclusively, so far as I could tell, to the decisions on obscenity and did not put in issue the striking work of the Court in other areas of first amendment concern..$^{28}$ Further, such a gap between public and judicial attitudes may be a healthy sign. The tradition has never been that freedom of speech was a value to be left to majority vote; indeed, that may be the whole point of the first amendment and of judicial review under it.

\section{I.}

At the Museum of Science and Industry in Chicago there is a chart which occupies a long wall and which graphs over time the changes in human technology. The time span is some 50,000 years, and the introduction of each technological advance-from the first crude stone used as a tool for digging to today's latest electronic or space age wonders-is entered on the graph. The result is a stunning visual impression of the acceleration of cultural inheritance. Man has made more major technical advances in the past 100 years than in the previous 49,900 !

26. It is arguable that the core of the Warren Court, at least for first amendment cases, has really been just the four: Justice Brennan, Justice Stewart, the Chief Justice, and Justice Harlan. While Justices Black and Douglas have joined in the decisions, they have often stood somewhat apart in matters of doctrine as in obscenity, libel, and congressional committee sequences.

27. You know-Ruth, Gehrig, Meusel, Lazzeri, Combs, Hoyt, et al.

28. However, The Chicago Tribune, Oct. 13, 1968, carried an editorial on the Court entitled, "Will the Supreme Court Mend Its Ways?" which listed and expressed displeasure over some eleven decisions inhibiting the control of subversive activities. 
There is a general analogy here to the making of law. Invention seems to breed invention, and precedent breeds more precedent. But I cite the Museum wall to make a specific point about the Warren Court. If one were to imagine a comparable scheme charting the incidence of first amendment cases from 1791 to date, the parallel would be striking indeed; we would get a proper sense of the accelerated accumulation of first amendment precedents in the past fifteen years. The point is, I think, a neutral one. It goes for the moment not to the quality of the Court's answers but to its willingness to confront first amendment questions at an unprecedented rate. The result is that a great part of the law, and a greater part of what is of interest today to the teacher or commentator, is the work of the Warren Court.

Even the quickest survey makes the point. All of the constitutional decisions on obscenity have come from this Court, starting with $\operatorname{Roth}^{28}$ in 1957; if one is interested in law and obscenity he will perforce find himself studying essentially the work of the Warren Court. $^{30}$ Similarly, the constitutional law on libel has-with the exception of Beauharnais ${ }^{31}$ in 1952-come from this Court, starting with New York Times' in 1964. And, moving to areas where there was some prior precedent, the impression is not much changed. Think what Watkins, ${ }^{33}$ Barenblatt, ${ }^{34}$ Sweezy, ${ }^{35}$ Uphaus, ${ }^{36}$ Braden, ${ }^{37}$ Wilkinson, ${ }^{38}$ Yellin, $^{39}$ Gibson, $^{40}$ and DeGregory ${ }^{41}$ have added to the law on congressional investigating committees; the precedents previously consisted of little more than Kilbourn $v$. Thompson ${ }^{42}$ in 1881, McGrain v. Daugherty ${ }^{43}$ in 1927, and Rumely v. United States ${ }^{44}$ in 1953. Or, to take one final ready example, think of the law on use of the public forum: the major stimulus to the development of this body of law provided by the Jehovah's Witnesses in the 1930's and

29. 354 U.S. 476 (1957).

30. See Kalven, supra note 7; Magrath, The Obscenity Cases: Grapes of Roth, 1966 Sup. Cr. Rev. 7.

31. Beauharnais v. Illinois, 343 U.S. 250 (1952).

32. 376 U.S. 254.

33. Watkins v. United States, 354 U.S. 178 (1957).

34. Barenblatt v. United States, 360 U.S. 109 (1959).

35. Swcezy v. New Hampshire, 354 U.S. 234 (1957).

36. Uphaus v. Wyman, 360 U.S. 72 (1959).

37. Braden v. United States, 365 U.S. 431 (1961).

38. Wilkinson v. United States, 365 U.S. 399 (1961).

39. Yellin v. United States, 874 U.S. 109 (1963).

40. Gibson v. Florida Legislative Investigation Comm., 372 U.S. 539 (1963).

41. DeGregory v. Attomey General of New Hampshire, 383 U.S. 825 (1966).

42. 103 U.S. 168.

43. 273 U.S. 135.

44. 345 U.S. 41. 
early 1940 ' $\mathrm{s}^{45}$ has been overshadowed by the notable contributions of the Warren Court in Garner v. Louisiana, ${ }^{46}$ Edwards v. South Carolina, ${ }^{47}$ Cox v. Louisiana, ${ }^{48}$ Brown v. Louisiana, ${ }^{49}$ and Adderley $v$. Florida. ${ }^{50}$

Let me approach the matter a little less impressionistically. Taking Lockhart, Kamisar, and Choper's casebook, Constitutional Rights and Liberties, we can make the point in rough quantitative terms. The book is intensely concerned with first amendment issues, and the latest edition ${ }^{51}$ devotes some 340 pages to them. The editors rate eighty-nine cases worthy of special study; of these, a total of fifty-five, or over 60 per cent, have been decided by the Warren Court.

There is perhaps one other way of putting into perspective how much the Warren Court has enriched the constitutional doctrine of freedom of speech, press, and assembly. It is to compare the classic book in the field, Chafee's Free Speech in the United States, first published in 1920 and republished in elaborated form in 1941, with the current corpus of law. A book today performing the function of Chafee's volume would look notably different, deal to a considerable degree with different principles, and confront to a considerable extent different problems. If the analytic density of the Chafee book were to be maintained, the contemporary treatment would surely require two volumes; and the second volume would be devoted to the work of the Warren Court.

II.

It is not feasible within the compass of this Article to attempt a systematic review of the results the Court has achieved in the various areas of first amendment law. I should prefer, therefore, to check off briefly some of the new ideas the Court has introduced into the field.

New York Times may have effected a major alteration in official thinking about free speech. To begin with, the Court introduced the attractive notion that the first amendment has a "central meaning" and thus suggested the possibility of a "core" theory of free speech. The central meaning suggested in Times appears to be the notion that seditious libel is not actionable.

It must be admitted that the promise of radical rethinking of the

45. See Kalven, The Concept of the Public Forum: Cox v. Louisiana, 1965 Sup. CT. Rev. 1.

46. Garner v. Louisiana, 368 U.S. 157 (1961).

47. 372 U.S. 229 (1963).

48. 379 U.S. 536 (1965).

49. 383 U.S. 131 (1966).

50. 385 U.S. 39 (1966).

51. 1967 . 
theory and rationale of the first amendment which this invites has not as yet been judicially pursued.52 The Court has been careful, however, to preserve the status of New York Times as a key precedent. ${ }^{63}$ The Court has also made visible a new kind of problem in Times and its sequelae: the question of whether falsity in fact as contrasted with falsity in doctrine is entitled to any protection. This problem arises when discussion of issues in the public domain is interlaced with statements of fact about particular individuals. The issue is whether in protecting the individual's interest in reputation or privacy we will give him a veto power over the general discussion. This was the problem in Times itself and again in Time Inc. v. Hill, Butts, and Associated Press v. Walker; it looms as a large issue since much public discussion appears to have this mixed quality. ${ }^{54}$ The dilemma is a difficult one, but the Court has confronted it and, to my mind, has made real progress toward a satisfactory solution.

Perhaps equally important is the abrogation of outmoded ideas by the Court; the most significant step here, I suggest, has been the great reduction in the status and prestige of the clear-and-presentdanger test. Immediately prior to the advent of the Warren Court, this test had a considerable claim as the criterion of the constitutionality of an exercise of governmental authority over communication. In limited areas the test may still be alive, but it has been conspicuous by its absence from opinions in the last decade. Since the test-whatever sense it may have made in the limited context in which it originated-is clumsy and artificial when expanded into a general criterion of permissible speech, the decline in its fortunes under the Warren Court seems to be an intellectual gain.

Another major conceptual contribution of the Warren Court has been development of the idea of self-censorship. A regulation of communication may run afoul of the Constitution not because it is aimed directly at free speech, but because in operation it may trigger a set of behavioral consequences which amount in effect to people censoring themselves in order to avoid trouble with the law. The idea has appeared in several cases, and, while the Court has not yet addressed a major opinion to it, it has all the earmarks of a seminal concept. The cases have varied in context from Speiser $v$.

52. See note 2 supra.

53. Kalven, The Reasonable Man and the First Amendment: Hills, Butts and IFalker, 1967 Sur. Cr. REv. 267, 308.

54. This appears to be an instance of a general problem. Compare Judge Hand's comment on another instance of utterances with "a double aspect." United States v. Dennis, 183 F.2d 201 (2d Cir. 1950). See also Kalven, supra note 7, at 11-12. 
Randall, ${ }^{55}$ to Smith v. California, ${ }^{58}$ to Time Inc. v. Hill. ${ }^{57}$ In Speiser the Court invalidated a state statute requiring affidavits of non-Communist affliation as a condition for a tax exemption. The vice was a subtle one: as the Court understood the state procedure, the affdavit was not conclusive; thus the burden of proof of nonsubversion was left on the applicant. The Court stated:

The vice of the present procedure is that, where the particular speech falls close to the line separating the lawful and the unlawful, the possibility of mistaken factfinding-inherent in all litigationwill create the danger that the legitimate utterance will be penalized. The man who knows that he must bring forth proof and persuade another of the lawfulness of his conduct necessarily must steer far wvider of the unlawful zone than if the State must bear these burdens. ${ }^{58}$..

In Smith the Court confronted an ordinance imposing strict criminal liability on the sellers of obscene books. Again, the Court found the vice in the chain of consequences such regulation might engender:

By dispensing with any requirement of knowledge of the contents of the book on the part of the seller, the ordinance tends to impose a severe limitation on the public's access to constitutionally protected matter. For if the bookseller is criminally liable without knowledge of the contents, and the ordinance fulfills its purpose, he will tend to restrict the books he sells to those he has inspected; and thus the State will have imposed a restriction upon the distribution of constitutionally protected as well as obscene literature. . . . The bookseller's self-censorship, compelled by the State, would be a censorship affecting the whole public, hardly less virulent for being privately administered. ${ }^{59}$

Finally, in the context of tort liability for "false light" privacy, the Court in Hill conceptualized the problem as one of triggering selfcensorship; it thus would give the publisher a conditional privilege defeasible only by actual malice:

We create grave risk of serious impairment of the indispensable service of a free press in a free society if we saddle the press with the impossible burden of verifying to a certainty the facts associated in a news article with a person's name, picture or portrait, particularly as related to nondefamatory matter. Even negligence would be a most elusive standard especially when the content of the speech itself affords no warning of prospective harm to another through falsity.

55. 357 U.S. 513 (1958).

56. 361 U.S. 147 (1959).

57. 385 U.S. 374 (1967).

58. 357 U.S. 513,526 (1958).

59. 361 U.S. $147,153-54$ (1959). 
... Fear of large verdicts in damage suits for innocent or merely negligent misstatement, even the fear of expense involved in their defense, must inevitably cause publishers "to steer ... . wider of the unlawful zone . ..."60

The Court is thus in command of a versatile concept which represents, I think, a fascinating addition to the vocabulary of first amendment doctrine. It should perhaps be acknowledged that the opinions in all three cases were written by Justice Brennan.

One other potentially powerful idea of the Warren Court should be noted: the principle that strict economy of means is required when communication is regulated. It is not enough that the end be legitimate; the means must not be wasteful of first amendment values. The seeds of this notion first appeared in Schneider v. New Jersey, ${ }^{61}$ decided in 1939, which invalidated a prohibition against distributing leaflets where the governmental objective was to prevent littering the streets. But the idea was given its fullest expression by the Warren Court in Shelton v. Tucker, ${ }^{62}$ which voided a state statute requiring each school teacher as a condition of employment to file annually an affidavit listing every organization to which he had belonged or contributed in the preceding five years. The Court found that, although the state had a legitimate interest in the organizational commitments of its teachers, the statute gratuitously overshot its target. Justice Stewart stated the principle this way:

In a series of decisions this Court has held that, even though the governmental purpose be legitimate and substantial, that purpose cannot be pursued by means that broadly stifle fundamental personal liberties when the end can more narrowly be achieved. The breadth of legislative abridgment must be viewed in the light of less drastic means for achieving the same basic purpose. ${ }^{63}$

It remains to be seen whether this principle, too, will be seminal. There is more than a suggestion in it of a preferred-position thesis. Legislation regulating communication may not be presumptively unconstitutional today, but under the economy principle it will not be entitled to, in Holmes' phrase, "a penumbra" of legislative convenience. ${ }^{84}$

60. 385 U.S. 374,389 (1967).

61. 308 U.S. 147.

62. 364 U.S. 479 (1960).

63. 364 U.S. at 479 .

64. Dissenting in Schlesinger v. Wisconsin, 270 U.S. 230, 241 (1926): ("But the law allows a penumbra to be embraced that goes beyond the outline of its object in order that the object may be secured.") There is another group of related cases dealing with vagueness and requiring precision in phrasing to avoid ambiguity. See, e.g., Elfbrandt v. Russell, 384 U.S. 11 (1966); Keyishian v. Board of Regents, 385 U.S. 589 (1967); Aptheker v. United States, 378 U.S. 500 (1964); United States v. Robel, 389 
III.

The momentum of the Warren Court in other areas of constitutional law has been the source of sustained controversy and criticism. ${ }^{65}$ Without attempting to assess the merits of such criticism in general, I should like to explore whether in the special area of free speech the Court's work is subject to similar disapproval.

It has frequently been objected that the Court has moved too fast and in giant steps rather than with the gradual deliberation appropriate to the judicial process, that its opinions have often displayed inadequate craftsmanship, that it has failed to confront the issues and to rationalize its results with appropriate rigor. However, if we consider for a moment the work of the Court in two important areas-obscenity and the scope of the power of congressional investigating committees-these criticisms do not appear warranted. To be sure there had been, as we noted, no constitutional decisions whatsoever on the obscenity issue prior to 1957. But that was simply because such cases had not come before the Court; there was no general consensus that such regulation was constitutional. In fact, there had long been recognized a tension between obscenity regulation and the first amendment. It is enough to cite the widespread praise of Judge Woolsey's decision and opinion in the Ulysses case ${ }^{6 B}$ to document the tension generally seen between the regulation of obscenity and the reach of the first amendment; by the time the Supreme Court entered the field in the Roth case, judges in other courts had explicitly noted the constitutional shadows. ${ }^{67}$

Moreover, in Roth the Court upheld the constitutionality of the obscenity regulation involved. In doing so, however, it recognized and attempted to define the constitutional limitations on such regulation. While in the past decade an unusual number of obscenity cases have reached the Supreme Court, the sequence of resulting decisions can fairly be characterized as involving the gradual resolution of limited and closely related problems on a case-by-case basis. Thus, Kingsley Pictures ${ }^{68}$ resolved the problems of thematic obscenity; Butler $v$. Michigan ${ }^{68}$ resolved the problems of regulation of

U.S. 258 (1967). Perhaps on close analysis the vagueness, economy, and self-censorship criteria can be made to converge.

65. Cf. Kurland, The Supreme Court 1963 Term-Foreword: "Equal in Origin and Equal in Title to the Legislative and Executive Branches of the Government", 78 HARv. L. REv. 143 (1964); A. Cox, supra note 24.

66. United States v. One Book Called "Ulysses," 5 F. Supp. 182 (S.D.N.Y. 1934), aff'd, 72 F.2d 705 (2d Cir. 1934).

67. See the opinions of Judge Curtis Bok in Commonwealth v. Gordon, $66 \mathrm{~Pa}$. D. \& C. 101 (1949); and the concurring opinion of Judge Jerome Frank in the court below in the Roth case itself, 237 F.2d 796 (2d Cir. 1956).

68. 360 U.S. 684 (1959).

69. 352 U.S. 380 (1957). 
general literature distribution keyed to what is suitable for children; and $\mathrm{Smith}^{70}$ dealt with permissible regulation of booksellers. Moreover, Manual Enterprises v. Day" added the element of "patent offensiveness" to the constitutional definition of obscenity, and Jacobellis $v$. Ohio" ${ }^{72}$ attached the element of "utterly without redeeming significance." If there has been a jarring note, it has come not in accelerating the liberation of arts and letters from obscenity censorship, but rather from the sudden move in the opposite direction in Ginzburg $v$. United States" ${ }^{73}$ by adding the perplexing "pandering" element to the constitutional test.

It is true that the Court has been conspicuously unsuccessful in pleasing commentators or in reaching any consensus within itself as to how to handle obscenity cases. It is possible to detect at least six different doctrinal positions among the nine Justices. But this is due, I would suggest, to the intrinsic awkwardness of the problem rather than to a judicial failure to take the cases seriously or to face the issues squarely. In any event, the Court cannot be criticized for rushing past existing precedent in order to abolish censorship altogether.

Similarly, in cases involving congressional investigating committees, and in particular the House Un-American Activities Committee, the Court, while recognizing a first amendment shadow, has inched along case by case in an attempt to develop a formula of limitation. Again, the sheer frequency of cases at the Supreme Court level within the last decade is astonishing. In a number of casesBarenblatt, ${ }^{74}$ Uphaus, $^{75}$ Braden, $^{76}$ and Wilkinson ${ }^{77}$-the Court has upheld committee power and refused to inquire into the motives of the congressmen. In Watkins, ${ }^{78}$ despite the stirring rhetoric of Chief Justice Warren's opinion, the actual decision was keyed to the technical requirement that the pertinency of the committee's questions must be made clear to a witness if he is to be legally compelled to answer. In Yellin, ${ }^{79}$ the decision adverse to the committee rested simply on the committee's failure to follow its own procedural rules; in Gibson, ${ }^{80}$ the Court was impressed by the committee's failure to establish a sufficient nexus or foundation for its questions; in DeGregory, ${ }^{81}$ the crucial factor was the staleness of the questions.

\footnotetext{
70. 361 U.S. 147 (1959).

71. 370 U.S. 478 (1962).

72. 378 U.S. 184 (1964).

73. 383 U.S. 463 (1966).

74. Barenblatt v. United States, 360 U.S. 109 (1959).

75. Uphaus v. Wyman, 360 U.S. 72 (1959).

76. Braden v. United States, 365 U.S. 431 (1961).

77. Wilkinson v. United States, 365 U.S. 399 (1961).

78. Watkins v. United States, 354 U.S. 178 (1957).

79. Yellin v. United States, 374 U.S. 109 (1963).

80. Gibson v. Florida Legislative Investigation Comm., 372 U.S. 539 (1963).

81. DeGregory v. Attorney General of New Hampshire, 983 U.S. 825 (1966).
} 
Thus far, the Court has recognized that compulsory disclosure to an investigating committee may inhibit freedom of speech and association, but it has found this loss a legitimate consequence of the state's interest in finding facts. Moreover, the Court has managed to withstand the argument of four dissenters ${ }^{82}$ who have urged repeatedly that committee inquiries into subversion violate the first amendment. Here as with obscenity the Court has not found a satisfactory solution to the problems posed, but it has worked at them steadily, with circumspection, and without taking giant libertarian steps.

The congressional committee cases suggest one final point about the Warren Court and its critics-a point on which Archibald Cox recently commented. ${ }^{83}$ Not infrequently the Court has been criticized for usurping power from other branches of government, for failing to seek solutions that would accommodate the separation of political power in our soriety. Yet in the congressional committee cases, although the Court has made evident its distaste for the excesses of committee inquiry, it has been careful when deciding against the committee to place its decision on grounds that would leave the power ultimately in Congress. Thus if the committee follows its own rules of procedure, if it makes the pertinency of its questions clear to the witness, if it avoids stale inquiries, and if it lays some foundation for examining the particular witness, the Supreme Court, as matters now stand, will ratify its power to compel answers to its questions.

We noted at the start that the topic of the Warren Court is an oblique, elusive one. Surely it would be easier to discuss straight away the substantive issues the Court has dealt with rather than to probe for some pattern of positions distinctive to the personality of this particular Court. Nevertheless, as we also said at the outset, there does seem to be a special trademark to this Court's work in the area of freedom of speech, press, and assembly. There is a zest for these problems and a creative touch in working with them. It has been noted that there are overtones of Alexander Meiklejohn in the Court's idiom. It may, therefore, not be inappropriate to turn to Mr. Meiklejohn for a final comment. Speaking of the principle of the first amendment, he once said: "We must think for it as well as fight for it." 84 The Warren Court in its enriching gloss on the amendment over the past fifteen years has done a good deal to help us do both.

82. See the dissents of Justices Black, Douglas, Brennan, and the Chief Justice in Barenblatt, Uphaus, Braden, and Wilkinson.

83. A. Cox, The WARREN COURT 104-08 (1968).

84. A. Mifiklejofin, Polmical freedom 6 (1960). 